\title{
Meningkatkan Hasil Belajar Matematika Materi Penjumlahan Dan Pengurangan Dengan Menggunakan Bahasa Daerah Pada Siswa Kelas I SDN Bedus Tahun Pelajaran 2017/2018
}

\author{
SUHARTI \\ Guru Kelas SDN Bedus Kecamatan Pujut \\ Kabupaten Lombok Tengah
}

\begin{abstract}
Abstrak. Tujuan penelitian ini adalah untuk mengetahui peningkatan hasil belajar Matematka materi Penjumlahan dan pengurangan dengan mengunakan bahasa daerah pada siswa kelas 1 SDN Bedus Tahun Pelajaran 2017/2018 yang berjumlah 39 orang siswa. Metode penelitian ini menggunakan metode penelitian tindakan kelas (PTK) yang berlangsung dalam dua siklus. Masing-masing siklus dilaksanakan sesuai rencana pelaksanaan pembelajaran (RPP) yang telah dibuat dan dibagi dalam 4 tahap yaitu tahap perencanaan, tahap pelaksanaan, tahap observasi dan evaluasi, serta tahap reflesi. Hasil belajar siswa pada prasiklus dilihat dari hasil ulangan harian dari 39 siswa yang tuntas hanya 15 orang siswa atau 38,46\% dan 24 orang siswa belum tuntas dengan porsetase ketuntasan sebesar 61,53 \% dengan rata - rata kelas sebesar 63,6 .Pada siklus I terjadi peningkatan jumlah siswa yang tuntas sebanyak 26 0rang siswa atau $66,66 \%$ dan siswa yang tidak tuntas sebanyak 13 atau 33,33 \%dengan nilai rata - rata kelas sebesar 68,46 terjadi peningkatan sebesar 4,86 poin dari prasiklus ke siklus I.Kemudian pada siklus II jumlah siswa yang tuntas sebanyak 36 siswa atau persentase ketuntasan sebesar 92,30 \% ,dan siswa yang belum tuntas sebanyak 3 siswa atau porsentase ketuntasan sebesar 7,69 \%dan nilai rata - rata kelas sebesar 81,28 terjadi peningkatan sebesar 12,82 poin dari siklus I ke Siklus II peningkatannya cukup signifikan.
\end{abstract}

\section{Kata Kunci : Peningkatan Hasil belajar, Bahasa daerah}

\section{PENDAHULUAN}

Bahasa merupakan bagian yang tidak dapat dipisahkan dari kehidupan manusia, karena dengan bahasa seseorang dapat menyampaikan maksud dan keinginan kepada orang lain. Dengan bahasa seseorang dapat berkomunikasi dan beradaptasi dengan manusia lain, seperti yang dikatakan oleh Ketidalaksanaan bahasa adalah sistem lambang bunyi arbitrer, yang digunakan oleh para kelompok sosial untuk bekerjasama, berkomunikasi dan mengidentifikasikan diri. Bahasa bersifat manusiawi, artinya bahasa sebagai alat komunikasi verbal hanya dimiliki oleh manusia. Pada dasarnya bahasa tersebut mempunyai dua aspek mendasar, yaitu aspek bentuk dan makna. Aspek bentuk berkaitan dengan bunyi, tulisan maupun struktur bahasa, sedangkan aspek makna berkaitan dengan leksikal, fungsional maupun gramatikalnya (Henry Guntur Tarigan, 2011: 6).

Dengan menggunakan Bahasa Daerah siswa lebih banyak memahami materi Jurnal Ilmiah Mandala Education penjumlahan dan pengurangan yang disampaikan dari pada memakai bahasa Indonesia karena lebih banyak siswa kelas 1 yang masih memakai bahasa ibu yaitu Bahasa teruwai kenapa demikian, karena dilihat dari hasil ulangan harian siswa yang rendah yaitu hanya 15 siswa tuntas atau $38,46 \%$ dari 39 dan siswa yang tidak tuntas sebanyak 24 orang atau sebesar 61,53 dimana KKM yang ditetapkan di SDN Bedus adalah 65 untuk pelajaran matematika tahun pelajaran 2017/2018 yaitu 70 dengan ketuntasan klasikal 85\%..

Dari hasil belajar siswa tersebut maka di temukan beberapa kendala dari para siswa kelas satu antara lain masih belum bisa menggunakan bahasa Indonesia dengan baik , dominan masih menggunakan bahasa Ibu. hal ini menuntut perubahan-perubahan di dalam pengelolaan pembelajaran atau mengelola peroses belajar mengajar, penggunaan alat bantu pelajaran yang menarik, strategi belajar mengajar, penggunaan bahasa mudah dipahami oleh siswa terlebih siswa kelas I 
yang pada semester I masih dominan dengan bahasa ibu.

Berangkat dari permasalahan tersebut peneliti menawarkan solusi untuk menggunakan bahasa daearah dalam pembelajaran sehingga tercapai tujuan pembelajaran yang telah direncanakan.untuk itu peneliti tertarik mengangkat judul penelitian" Meningkatkan Hasil Belajar Matematika Materi Penjumlahan dan Pengurangan dengan Menggunakan Bahasa Daerah pada Siswa Kelas I SDN Bedus Tahun Pelajaran 2017/2018"

\section{Rumusan Masalah}

Berdasarkan uraian latar belakang masalah di atas, dapat dirumuskan permasalahan sebagai berikut: Bagaimanakah Meningkatkan Hasil Belajar Matematika Materi Penjumlahan dan Pengurangan dengan Menggunakan Bahasa Daerah pada Siswa Kelas I SDN Bedus Tahun Pelajaran 2017/2018?

\section{Tujuan Penelitian}

Berdasarkan rumusan masalah di atas, maka tujuan yang ingin dicapai dalam penelitian ini adalah untuk Meningkatkan Hasil Belajar Matematika Materi Penjumlahan dan Pengurangan dengan Menggunakan Bahasa Daerah pada Siswa Kelas I SDN Bedus Tahun Pelajaran 2017/2018.

\section{Manfaat Penelitian}

Manfat [penelitian ini ada dua yaitu manfaat secara teoritis dan manfaat secara praktis. Secara teoritis hasil penelitian ini dapat berguna untuk menambah wawasan keilmuan yang berkaitan dengan penggunaan bahasa daerah dalam meningkatkan pemahaman matematika pada siswa kelas 1 Sekolah Dasar. Seangkan sera praktis penelitian dapat meningkatkan Kemampuan Siswa dalam memahami materi prnjumlahan dan pangurangan pada siswa kelas 1 SD sihingga dapat meningkatkan hasil pembelajaran

\section{KAJIAN PUSTAKA}

\section{Pengertian Bahasa Daerah}

Bahasa Daerah sebagai bahasa pengantar pada tingkat permulaan sekolah dasar. Di daerah tertentu bahasa daerah boleh dipakai sebagai bahasa pengantar di dunia pendidikan tingkat sekolah dasar sampai dengan tahun ketiga (kelas tiga). Setelah itu, harus menggunakan bahasa Indonesia, kecuali daerah-daerah yang mayoritas masih menggunakan bahasa daerah sebagai bahasa ibu.

\section{Macam-macam Bahasa Daerah Bahasa Sasak Lombok}

Bahasa sasak dipakai oleh masyarakat lombok, provinsi Nusa Tenggara Barat. Bahasa ini mempunyai tradisi sebagaimana bahasa Bali dan bahasa Jawa. Bahasa sasak mempunyai dialek-dialek yang berbeda menurut wilayah, bahkan dialek di kawasan Lombok Tengah sulit dipahami oleh para penutur sasak lainya. Sebagai contoh, kawasan antar tetangga (RW) yang hanya berjarak 500 meter sudah memiliki dialek yang sangat berbeda(Bahrie,2009).

Tabel 2.1

Kosa Kata Bahasa Sasak

\begin{tabular}{|c|l|l|}
\hline No & Bahasa sasak & Bahasa Indinesia \\
\hline 1 & Aku & Saya \\
\hline 2 & Side & Kamu \\
\hline 3 & Tampi Asih & Terima kasih \\
\hline 4 & Kelor & Makan \\
\hline 5 & Bale & Rumah \\
\hline
\end{tabular}

\section{Bahasa Jawa}

Bahasa Jawa dituturkan oleh masyarakat Indonesia terutama di pulau Jawa bagian tengah dan timur. Namun, di pulaupulau yang lainnya juga terdapat penutur bahasa Jawa. Bahkan di luar negeri pun juga terdapat penutur-penutur bahasa Jawa, di antaranya negara Suriname, Kaledonia Baru, Malaysia, dan Singapura. Bahasa Jawa memiliki beberapa tingkatan, seperti Ngoko, Madya, dan Krama. Menurut data sensus tahun 2000, penutur bahasa Jawa di Indonesia adalah sebanyak 84 juta jiwa lebih.

\section{Bahasa Bali}

Bahasa Bali adalah bahasa yang dituturkan oleh Masyarakat di pulau Bali, Lombok, dan sedikit ujung timur pulau Jawa. Di Lombok, bahasa Bali dituturkan terutama di sekitar Praya Lombok Tengah, sedangkan di pulau Jawa dituturkan di beberapa desa di kabupaten Banyuwangi. Sebagaimana bahasa Jawa, bahasa Bali juga terdapat beberapa tingkatan, seperti Bali Kasar, Bali Madya, dan Bali Alus. Bahasa Bali memiliki berbagai 
macam dialek, di antaranya dialek Dataran Rendah Bali (Klungkung, Karangasem, Buleleng, Gianyar, Tabanan, Jembrana, Badung), Dataran Tinggi Bali ("Bali Aga"), dan Nusa Penida (ww.buku hindu.om\% fbuku\%3 detail diambil09 maret2016 pukul 09.00 wita).

\section{Fungsi dan Kegunaan Bahasa Daerah}

Fungsi bahasa daerah yaitu (1) Bahasa Daerah sebagai pendukung Bahasa Nasional, (2) Bahasa Daerah sebagai bahasa pengantar pada tingkat permulaan sekolah dasar di daerah tertentu, (3) Bahasa Daerah sebagai sumber kebahasaan untuk memperkaya Bahasa Indonesia. Adapun kegunaan bahasa daerah; (1) Sebagai lambang kebanggaan daerah, (2) Lambang identitas daerah, (3) Alat penghubung di dalam keluarga dan masyarakat daerah

\section{Materi Penjumlahan dan Pengurangan Materi Penjumlahan}

Materi penjumlahan dan pengurangan ini diajarkan di SDN Bedus kecamatan Pujut Judul: Matematika aktif untuk sekolah dasar kelas 1 jilid I penerbit: erlangga Oleh $\mathrm{M}$. Khafid Kasri, Gunanto. penerbit Erlangga.

Ada suatu kasus pada anak SD kelas 1 - Saat anak baru masuk kelas 1 SD, untuk pertama kalinya dia bertemu dengan pelajaran Matematika yang sesungguhnya. Berhasil atau tidaknya anak dalam pelajaran matematika kelas 1 itu akan berdampak besar pada pandangannya terhadap pelajaran matematika kelak menyeramkan bagi si anak dikemudian hari.

Kalau kita merujuk pada materi pelajaran Matematika pada kelas 1 semester 1, ada beberapa kemampuan yang harus dimiliki anak sebelum masuk SD (1) Memahami bilangan 0 sampai 10 dengan menggunakan jari, (2) Anak harus mampu berhitung maju 0 sampai 10 dengan mengucapkannya (nol,satu,dua,......dst sampai sepuluh), atau mengurutkan bilangan dari yang terkecil, (3) Mampu memahami makna bilangan (misal bila ada gambar 5 apel, anak mampumenghitungnya), (3) Mampu menulis lambang bilangan dan nama

bilangan.

Contoh:

Telu atum terombok due atum pire jarin = Lime atum $\cong$ tiga pensil dua pensil $=1$ lima pensil $3+2=5$

(4) Mampu menghitung mundur (mengucap angka) dari bilangan 10 sampai 0 Contoh : Sepulu, siwaq, baluq, pituq,enem, lime dan sebagainya

contoh berhitung mundur : Sepuluh,Sembilan, Delapan,Tujuh,Enam,Lima dst secara urut. (mengurutkan bilangan dari yang terbesar).

Tahap 2. Yang merupakan tahap berikutnya dibuatkan model, yaitu model semi konkret (model gambar) yang tidak menggunakan benda-benda nyata seperti buku-buku sebenarnya tetapi cukup dengan gambar .

\section{Materi Pengurangan}

1) Mengurangkan satu bilangan lain (1 sampai dengan 5)

a. Nane jakn bahas kurangan masalah irup sejelo-jelo misaln lime buak jeruk tekurangan sik due buak jeruk pire jarin $5-2=3$

b. Sekarang kita akan membahas tentang kehidupan sehari-hari contoh lima buah jeruk dikurangi dua jeruk berapa jadinya $5-2=3$

2) 4 bunderan -2 bunderan $=2$ bunderan

Contoh soal pengurangan

$2-1=1$

$4-2=2$

$5-2=3$

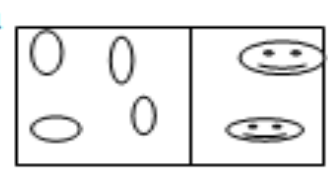

\section{Konsep Kemampuan dan Pemahaman}

Pemahaman didefinisikan proses berpikir dan belajar. Dikatakan demikian karena untuk menuju kearah pemahaman perlu diikuti dengan belajar dan berpikir. Pemahaman merupakan proses, perbuatan dan cara memahami. Sedangkan menurut Anas Sudijono, pemahaman adalah kemampuan seseorang untuk mengerti atau memahami sesuatu setelah sesuatu itu diketahui dan dan ingat. Dengan kata lain, memahami adalah mengetahui tentang sesuatu dan dapat melihatnya dari berbagai segi (Anas Sudijono. www.refrensimakalah.com $>$ home $>$ pembelaja ran. diambil tanggal 09 Maret 2016, pukul 09.00 Wita) 
Kemampuan pemahaman matematis adalah salah sat tujuan penting dalam pembelajaran, memberikan pengertian bahwa materi-materi yang diajarkan kepada siswa bukan hanya sebagai hafalan, namun lebih dari itu. Dengan pemahaman siswa dapat lebih mengerti akan konsep materi pelajaran itu sendiri. Hal ini sesuai dengan Hudoyo yang menyatakan bahwa mengajar adalah agar pengetahuan yang disampaikan dapat dipahami peserta $\operatorname{didik}\left({ }^{1}\right.$ Hudoyo, Pendidikan Matematika 1(Jakarata: Hak Cipta.2006 ),hal. 61)

\section{Pengertian Matematika}

Kata matematika berasal dari bahasa latin, manthhanein atau mathema yang berarti" belajar atau hal yang dipelajari." Sedangkan dalam bahasa belanda wiskunde atau ilmu pasti, yang berkaitan dengan penalaran. Depdiknas mengemukakan matematika yaitu memiliki bahasa dan aturan yang terdefinisi dengan baik, penalaran yang jelas dan sistematis, dan struktur atau keterkaitan antar konsep yang kuat.

Pada usia siswa sekolah dasar (7-8 tahun sehingga 12-13 tahun), menurut teori kognitif piaget termasuk pada tahap oprasional konkrit. Berdasarkan perkembangan kognitif ini, maka anak usia sekolah dasar pada umumnya mengalami kesulitan dalam memahami matematika yang bersifat abstrak. Karena keabstrakannya matematika relatif tidak mudah untuk dipahami oleh siswa sekolah dasar pada umumnya.

Matematika merupakan salah satu disiplin ilmu yang dapat meningkatkan kemampuaan berpikir berargumentasi, memberikan distrubusi dalam penyelesaian masalah sehari-hari dan dalam dunia kerja, serta memberikan dukungan dalam mengembangkan ilmu pengetahuan dan teknologi. Kebutuhan akan mengaplikasi matematika saat ini dan masa depan tidak hanya untuk keprluan sehari-hari, tetapi terutama dalam dunia kerja, dan untuk mendukung perkembangan ilmu pengetahuan. Oleh karena itu, matematika sebagai ilu dasar perlu dikuasai dengan baik oleh siswa, terutama sejak usia sekolah dasar.

\section{Karakteristik Pembelajaran Matematika}

Menurut Soedjadi (1994:1), meskipun terdapat berbagai pendapat tentang matematika yang tampak berlainan antara satu sama lain, namun tetap dapat ditarik ciri-ciri atau karekteristik yang sama, antara lain: (a) Memiliki Objek Kajian Abstrak, (c) Bertumpu pada kesepakatan, (d) Berpola pikir deduktif, (e) Memiliki simbol yang kosong dari arti, (f) Memperhatikan semesta pembicaraan, (g) Konsisten dalam sistemnya (Soedjadi. Bahan Pelatihan dan Penelitian Matematika. http//.penelitian matematika. 01wita.17-08-2015. Hal ini berarti, bahwa belajar matematika merupakan proses untuk menghubungkan materi yang dipelajari dengan pemahaman yang dimiliki.

\section{Penggunaan Bahasa Daerah pada Pembelajaran Matematika}

Menurut Galileo Galilei (1564-1642), seorang ahli matematika dan astronomi dari Italia,"Alam semesta itu bagaikan sebuah buku raksasa yang hanya dapat dibaca kalau orang mengerti bahasanya dan akrab dengan lambang dan huruf yang digunakan di dalamnya. Dan bahasa alam tersebut tidak lain adalah matematika. Berbicara mengenai matematika sebagai bahasa, maka pertanyaan yang muncul kemudian adalah dalam sudut pandang mana matematika itu disebut sebagai bahasa, dan apa perbedaan antara bahasa matematika dengan bahasa-bahasa lainnya (Galileo Galilei. Bahasa dan Matematika dalam komunikasi. http//.penelitian matematika. 01wita.17-08-2015)

Merujuk pada pengertian bahasa di atas, maka matematika dapat dipandang sebagai bahasa karena dalam matematika terdapat sekumpulan lambang/simbol dan kata (baik kata dalam bentuk lambang, misalnya "3" yang melambangkan kata "lebih besar atau sama dengan”, maupun kata yang diadopsi dari bahasa biasa, misalnya kata "fungsi" yang dalam matematika menyatakan suatu hubungan dengan aturan tertentu antara unsur-unsur dalam dua buah himpunan)

\section{METODE PENELITIAN}

\section{Jenis Penelitian}

Adapun jenis penelitian yang dipakai dalam penelitian ini adalah penelitian tindakan kelas. Penelitian tindakan kelas 
(PTK) adalah penelitian yang dilakukan guru/peneliti di dalam kelas, dengan tujuan untuk memperbaiki kinerja guru sehingga hasil belajar siswa menjadi meningkat (Wardani. 2003: 60). Penelitian ini merupakan penelitian tindakan (action research), karena penelitian dilakukan untuk memecahkan masalah pembelajaran di kelas. Penelitian ini juga termasuk penelitian deskriptif, sebab menggambarkan bagaimana suatu teknik pembelajaran diterapkan dan bagaimana hasil yang diinginkan dapat dicapai..

\section{Tempat, Waktu dan Subyek Penelitian}

Penelitian tindakan kelas (PTK) ini dilaksanakan di SDN Bedus Tahun Pelajaran 2017/2018 pada semester ganjil periode Agustus s/d Oktober dengan jumlah siswa 39 orang yang terdiri dari 19 orang siswa laki laki dan 20 orang siswa perempuan.

\section{Rancangan Penelitian}

Rencana penelitian merupakan semua proses yang diperlukan dalam perencanaan dan pelaksanaan penelitian. Penelitian tindakan kelas ini bertujuan untuk memperbaiki dan meningkatkan evektivitas metode mengajar, pemberian tugas kepada siswa, penilaian dan lain sebagainya(Suharsimi Arikunto. 2013: 85).

Dalam penggunaan prosedur Penelitian Tindakan Kelas yaitu dengan siklus terdiri atas perencanaan, perlaksanaan tindakan, observasi, evaluasi dan refleksi. Pelaksanaan prosedur pengembangan yang digunakan dapat disajikan seperti gambar berikut.

Pendekatan penelitian yang dipakai oleh peneliti dalam penelitian ini adalah pendekatan kualitatif dan kuantitatif. Pendekatan kualitatif dan kuantitatif merupakan suatu pendekatan penelitian yang mengambil datanya selalu menggunakan kuisioner berupa lembar observasi, tetapi juga tetap dituntut berada di lapangan untuk selalu memantau perkembangan atau perubahan yang ada (Wardhani, dkk 2007: 24).

\section{Jenis Instrument dan Cara Penggunaannya}

Insrtumen penelitian adalah alat yang digunakan untuk mengukur fenomena alam maupun sosial yang diamati. Sedangkan menurut pendapat Suharsimi Arikunto instrument penelitian adalah alat atau fasilitas yang digunakan oleh penelitian dalam mengumpulkan data agar pekerjaan lebih mudah dan hasilnya lebih baik dalam arti lebih cermat, lengkap dan sistematis sehingga mudah diolah (Suharsimi. 2002;136).. Dari kedua pendapat di atas, dapat disimpulkan bahwa instrument penelitian adalah alat bantu yang digunakan untuk mengumpulkan data dalam penelitian ini adalah tes

\section{Pelaksanaan Tindakan}

Pelaksanaan kegiatan belajar mengajar dilaksanakan dengan jumlah siswa 39 orang siswa. Dalam hal ini peneliti bertindak sebagai guru. Adapun peroses belajar mengajar mengacu pada rencana pelajaran yang telah dipersiapkan.

\section{Pengolahan data Hasil Belajar}

Hasil belajar dinyatakan dengan nilai atau skor setelah mengerjakan suatu tugas atau tes. Untuk mengetahui hasil belajar siswa, hasil tes belajar dianalisis secara deskriptif yaitu dengan:

\section{Ketuntasan Individu}

Setiap siswa dalam proses belajar mengajar dikatakan tuntas secara individu terhadap materi apabila siswa mamapu memperoleh nilai berdasarkan nilai ketuntasan kriteria minimal yaitu 70 yang telah ditetapkan di SDN Bedus.

\section{Ketuntasan Klasikal}

Ketuntasan klasikal telah di capai apabila terget pencapaian ideal $\geq 86 \%$ dari jumlah siswa dalam kelas.

Keterangan:

$$
K K=\frac{n_{1}}{n} \times 100 \%
$$

$$
\mathrm{KK}=\text { ketuntasan klasikal }
$$

$\mathrm{n}_{1}=$ jumlah siswa yang mendapat nilai berdasarkan KKM

$\mathrm{n}$ = jumlah siswa yang ikut tes.

\section{HASIL DAN PEMBAHASAN}

siklus I

Penelitian tahap siklus I dilaksanakan pada hari Senin 4 Agustus 2017 dilaksakan selama 2 jam pelajaran ditambah dengan 1 jam evaluasi,hasil belajar siswa

Berdasarkan hasil pengolahan nilai diperoleh data sebagai berikut nilai rata- rata siswa sebesar 68,46 dengan jumlah siswa 
yang tuntas sebanyak 26 orang atau sebesar $66,66 \%$ dari jumlah siswa 29 orang kemudian jumlah siswa yang tidak tuntas sebanyak 13 orang atau sebesar 33,33 \% .ini disebabkan karena guru masih belum bisa memamfaatkan waktu dengan baik,sehingga penelitian ini akan dilanjutkan ke Siklus Berikutnya karena ketuntasan klasikal yang ditargetkan belum tercapai yaitu $\geq 80$.

\section{Pelaksanaan Siklus II \\ Tahap Perencanaan}

Adapun perencanaan yang dipersiapkan dalam siklus II sama dengan langkah pada siklus I hanya mematangkan dan penyempurnaan terhadap perencanaan dan persiapan yang masih kurang pada siklus sebelunya

Pada siklus 2 ini dilakukan pembelajaran untuk memperbaiki siklus 1 dilaksanakan pada hari kamis tanggal 14 september 2017, materi yang diajarkan soal cerita penjumlahan dan pengurangan dalam kehidupan sehari hari.

Dari hasil belajar diperoleh data sebagai berikut Rata- rata yang diperoleh sebesar 81,28 dengan jumlah siswa yang tuntas sebanyak 36 orang atau sebesar $92,30 \%$ dari 29 siswa, kemudian jumlah siswa yang tidak tuntas sebanyak 3 orang atau sebesar $7,69 \%$.ini disebabkan karena guru sudah mantap untuk menghilangkan kendala yang dialami pada siklus I.Pada tahap ini terjadi peningkatan hasil yang cukup signifikan,disamping itu ketuntasan belajar secara klasikal telah tercapai yaitu $92,30 \%$ maka ,penelitian ini dihentikan sampai pada siklus II.

\section{Pembahasan}

Penelitian ini dilaksanakan sesuai dengan prosedur penelitian tidakan.Penelitian tindakan pada siklus I dilaksanakan pada hari Senin 4 Agustus 2017 kemudian setelah selesai evaluasi maka didapatkan data sebagai berikut Rata- rata hasil belajar yang diperoleh sebesar 68,46 dengan jumlah siswa yang tuntas sebanyak 26 orang atau sebesar $66,66 \%$ kemudian jumlah siswa yang tidak tuntas sebanyak 13 orang atau sebesar 33,33 $\%$.ini disebabkan karena guru masih belum bisa memamfaatkan waktu dengan baik, siswa masih kurang antusias dalam pembelajaran berhitung ,sehingga penelitian ini akan dilanjutkan ke Siklus Berikutnya karena ketuntasan klasikal yang ditargetkan belum tercapai yaitu $\geq 80$.

Kemudian penelitian pada siklus II dilaksanakan pada hari kamis 14 september diperoleh data sebagai berikut Rata- rata yang diperoleh sebesar 81,28 dengan jumlah siswa yang tuntas sebanyak 36 orang atau sebesar 92,30\% kemudian jumlah siswa yang tidak tuntas sebanyak 3 orang atau sebesar 7,69\% .ini disebabkan karena guru sudah mantap untuk menghilangkan kendala yang dialami pada siklus I. Pada tahap ini terjadi peningkatan hasil yang cukup signifikan,disamping itu ketuntasan belajar secara klasikal telah tercapai yaitu $92,30 \%$ maka ,penelitian ini dihentikan sampai pada siklus II. Dari data yang diperoleh bisa dilihat peningkatan nilai rata rata dari siklus I ke siklus yaitu sebesar 12,82 poin ,kemudian ketuntasa belajar dari siklus I ke Siklus II meningkat sebesar 25,65 poin sehingga penelitian ini dihentikan sampai pada siklus II.

\section{KESIMPULAN}

Kesimpulan yang dapat diambil dalam penelitian ini adalah dengan meningkatkan Hasil Belajar Matematika Meteri penjumlahan dan pengurangan dengan menggunakan Bahasa Daerah pada Siswa kelas I SDN Bedus tahun pelajaran 2017/2018 . Penelitian ini dilaksanakan dalam II siklus Pada siklus ke II terjadi peningkatan hasil yang cukup signifikan,disamping itu ketuntasan belajar secara klasikal telah tercapai yaitu 92,30\% maka ,penelitian ini dihentikan sampai pada siklus II. Dari data yang diperoleh bisa dilihat peningkatan nilai rata rata dari siklus I ke siklus yaitu sebesar 12,82 poin ,kemudian ketuntasa belajar dari siklus I ke Siklus II meningkat sebesar 25,65 poin sehingga penelitian ini dihentikan sampai pada siklus II

.Pada siklus I jumlah siswa yang tuntas sebanyak 26 siswa kemudian pada siklus II menjadi 36 siswa yang tuntas belajar ,dan jumlah siswa yang tidak tuntas pada siklus I, 13 orang kemudian pada siklus II yang tidak tuntas menjadi 3 orang sehingga 
dikatakan terjadi peningkatan yang cukup signifikan.

Dari hasil pembahasan diatas maka dapat di simpulkan bahwa penggunaan bahasa daerah dapat meningkatkan hasil belajar Matematika materi penjumlahan dan pengurangan pada kelas I SDN Bedus.

\section{DAFTAR PUSTAKA}

Anas Sudijono. $\underline{\text { www.refrensi }}$ makalah.com>home>pembelajaran. diambil tanggal 09 Maret 2016, pukul 09.00 Wita

Bahrie. dkk, Bahan Ajar Muat Lokal. Cet.II, (Lombok : KSU Prima Guna, 2009.

Galileo Galilei. Bahasa dan Matematika dalam komunikasi. http//.penelitian matematika. 01wita.17-08-2015.

Henry Guntur Tarigan. Pengajaran Pemerolehan Bahasa. (Bandung: Angkasa, 2011),

Hudoyo, Pendidikan Matematika 1(Jakarata: Hak Cipta.2006 )

Isjoni, Guru Sebagai Motivator Perubahan (Jakarta : Pustaka Pelajar,2009)

Kunandar, Langkah Penelitian Tindakan Kelas Sebagai Pengembangan Profesi Guru, (Jakarta:PT Rajawali Pers, 2011),

Nana Sudjana, Dasar Dasar Proses Belajar Mengajar, (Bandung: Sinar Baru Algensindo, 2014),

Nurkencana, dkk. Evaluasi Hasil Belajar (Surabaya: Usaha Nasional. 1990),

Nurkencana, dkk. Evaluasi Hasil Belajar (Surabaya: Usaha Nasional. 1990), Sensus, "Penutur Bahasa Daerah", dalam http/www.Alamin.net/,diambil tanggal 09 Maret 2016, pukul 09.00 Wita Soedjadi. Bahan Pelatihan dan Penelitian Matematika. http//.penelitian matematika. 01wita.17-08-2015.

Suharsimi Arikunto. Prosedur Penelitian Suatu Pendekatan Praktik. (Jakarta: Rineka Cipta,2013.

Wardani. Statistika Untuk Penelitian. (Bandung : Alfabeta, 2003),

Wardhani,dkk. Penelitian Tindakan Kelas (Jakarta: Universitas Terbuka,2007), 